\title{
Genetic discrimination in foreign legislation and law- enforcement practice
}

\author{
Daria Ponomareva ${ }^{1, *}$, Aleksey Kubyshkin ${ }^{2}$ \\ ${ }^{1}$ Kutafin Moscow State Law University (MSAL), Department of Legal Practice, partner of the Scientific Collaboration "Legal Genomics \\ Developments Alliance (LeGenDA)", Sadovaya-Kudrinskaya Street 9, Moscow, 125993, Russia \\ ${ }^{2}$ Advocate at Advocate's Office "SanctaLex" of the Moscow City Bar Association, leading partner of the Scientific Collaboration "Legal \\ Genomics Developments Alliance (LeGenDA)", Talalikhina str., 2/1 build. 4, Moscow, 109147, Russia
}

\begin{abstract}
The article is devoted to the problematic issues of legal regulation of public relations arising from protection against discrimination based on genetic status in the legislation and law enforcement practice of a number of foreign countries (Australia, Canada, the United States of America). The authors analyzed the concept of discrimination based on genetic status, formulated in the legal acts of states; an attempt was made to present their own interpretation of this term. The article provides an overview of the international legal framework for the regulation of public relations arising from countering discrimination based on genetic status, as well as key acts of leading foreign jurisdictions. The authors paid special attention to the analysis of law enforcement (judicial) practice, illustrating the problems associated with genetic discrimination, the main directions of the development of such practice are highlighted. In conclusion, the authors contemplate on the advisability of implementing relevant foreign experience into the Russian legal system
\end{abstract}

\section{Introduction}

Over the past decades, human society has become much more aware of the influence of genetic factors on the occurrence of diseases. Unfortunately, it must be stated that the information obtained as a result of genetic testing is not always accurate and reliable, and its probabilistic value is very limited. That is why, at the level of individual states, the possibility of carrying out genetic testing and the availability of genetic information raises an understandable public concern, especially given the fact that many subjects of public relations not related to the medical profession (insurance companies, employers) are demonstrating a growing interest in individual genetic information.

At both the national and global (international) levels, discussions continue on the balance that needs to be struck between protecting individuals from the misuse of genetic information and the interests of public institutions. In addition, the issue of minimizing the risks associated with the increased availability of genetic information, which often becomes a reason for the implementation of discriminatory practices, is of particular interest.

This article provides a detailed overview of international and national legal frameworks for combating discrimination based on genetic status, as well as relevant jurisprudence. Based on a detailed analysis of the legislation and case law in the United
States of America, Australia and Canada and at the international level, the article is intended to answer questions related to the problems of legal regulation of the use of genetic information in various spheres of social life.

\section{The Definition of Genetic Discrimination}

Consideration of the concept of discrimination based on genetic status (genetic discrimination) is impossible without answering the question: what is discrimination per se? The understanding of this term is reduced to a negative or prejudiced attitude towards a person, or the deprivation of certain rights based on the presence of some characteristics/traits. At the same time, it should be noted that at the international and national level there is no single approach to the definition in question. In addition, several basic sources of international law (Universal Declaration of Human Rights 1948, International Covenant on Civil and Political Rights 1966, International Covenant on Economic, Social and Cultural Rights 1966, International Convention on the Elimination of All Forms of Racial Discrimination 1965, European Social Charter 1996) contain only a general prohibition of discrimination without any specification of what constitutes discrimination [1].

One of the first legal definitions of discrimination at the international level can be found in Convention No. 111: Convention concerning Discrimination in Respect

Corresponding author: ponomard@yandex.ru 
of Employment and Occupation, 1958. Accordingly, discrimination constitutes a violation of the rights enshrined in the Universal Declaration of Human Rights. An expansive approach to the definition of discrimination is applied in the 1968 UNESCO Convention against Discrimination in Education. Article 1 of this Convention provides that the term "discrimination" includes any distinction, exclusion, limitation or preference. This, being based on race, colour, sex, language, religion, political or other opinion, national or social origin, economic condition or birth, has the purpose or effect of nullifying or impairing equality of treatment in education. Thus, the Convention formulates possible types of discrimination, including racial, gender, ethnic discrimination, etc. [2].

It is curious to mention that these acts do not contain discrimination based on genetic status. Genetic discrimination is mentioned in Article 6 of the UNESCO Universal Declaration on the Human Genome and Human Rights of 1997, as well as in Article 7 (a) of the 2003 UNESCO International Declaration on Genetic Data. The general prohibition of discrimination based on genetic heritage is contained in article 11 of the Council of Europe Convention for the Protection of Human Rights and Dignity of the Human Being with regard to the Application of Biology and Medicine: 1997 Convention on Human Rights and Biomedicine (Oviedo Convention). However, none of the designated acts discloses the concept of genetic discrimination [3].

In this regard, it is not at all surprising that the development of the concept of genetic discrimination was carried out at the national level. In general, genetic discrimination is understood as a negative attitude towards a person, based solely on the characteristics of his genotype. Differential treatment due to genetic status is often rational and may be considered as a necessary social factor. In particular, we can talk about those cases when the employer needs to pay attention to such indicators of his physical health as visual acuity, hearing, endurance, etc. due to the specifics of the vacant position for which the applicant claims. Cases of negative attitude towards a person based on the phenotypic expression of a genetic characteristic fit well into the framework of legislation on disability and health status (here it is worth paying attention to the US Disability Act) [4]. Increasingly, in practice, there are cases of discriminatory attitudes towards physically healthy people, who have only a certain risk of disability, and not a real disability at the present time.

Discrimination based on genetic status (genetic discrimination) is distinguished from discriminatory attitudes in connection with illness or disability. Since the sources of law, both international and national, do not always contain a clear definition of genetic discrimination, it makes sense to turn to legal doctrine. A number of European researchers (Lapham et al.) are turning to an expanded interpretation of the concept of genetic discrimination, which includes a negative attitude towards a person, both due to the presence of a genetic predisposition to a particular disease, and the actual disease. Thus, we are talking about the coincidence of phenotypic and genotypic characteristics [5].

A number of researchers, on the contrary, share a narrow approach to the definition of genetic discrimination (Mark A. Hall and Stephen S. Rich), focusing only on hereditary predisposition to the disease. At the same time, both the first and the second group of researchers consider genetic discrimination to be an unacceptable phenomenon from both legal and ethical points of view [6].

Nonetheless, there is also an extreme, radical view of the concept of genetic discrimination, formulated by Colin S. Diver and Jane Maslow Cohen. Within the framework of their approach, discriminatory treatment of people due to genetic status is an acceptable practice from the point of view of law and morality, since it is "a socially necessary economic tool for allocating resources and calculating risks" [7]. In this context, the prohibition of genetic discrimination hampers the effective regulation of markets, which involves ensuring the transparency of genetic information.

The absence of a clearly formulated definition of genetic discrimination at the international level, the difference in approaches to the definition of this concept at the national level and in the legal doctrine pose problematic issues for legislators and law enforcement officials, including the following:

a) Is genetic discrimination a legal means differentiation of risks to ensure economic growth or is it a social evil from which it is necessary to protect human society?

b) If genetic discrimination is considered as an illegal practice, which groups of people and with which diseases should be protected first?

c) Should the list of subjects to be protected from genetic discrimination be open?

\section{Genetic Discrimination and International Law}

The Universal Declaration of Human Rights, adopted by the UN General Assembly in 1948, in its article 5 provides that "no one shall be subjected to torture or to cruel, inhuman or degrading treatment or punishment." The International Covenant on Civil and Political Rights of 1966 contains a similar provision, only with an emphasis on medical and scientific experimentation, to which no one should be subjected without free consent (article 7). The ethical and legal provisions of acts in the field of biomedicine concretize these framework provisions of the most important international documents in the field of human rights. In this context, the Declaration of Helsinki, adopted in 1964 by the World Medical Association and since that time has been repeatedly amended, is noteworthy.

This document, being an act of "soft law", nevertheless, became the basis for the development of legally binding provisions at the international, regional and national levels. The Declaration includes ethical and legal guidelines for conducting research with the participation of ordinary people and scientists, including 
the legal aspects of informed consent and the revision of research protocols. In addition, the 2016 International Guidelines on the Ethics of Biomedical Research Involving Human Subjects, adopted by the World Health Organization, stipulate that all research in the field of biomedicine should be carried out in accordance with three basic ethical principles, including: respect for the individual, integrity, fairness [8].

In 1997, the human genome becomes a special object of international law regulation. It was this year that the General Conference of UNESCO adopted the Universal Declaration on the Human Genome and Human Rights. The Preamble to this document indicates that while research on the human genome has great potential in promoting individual and public health and well-being, such research should be conducted with a view to prohibiting all forms of discrimination based on genetic characteristics. The legal framework for combating discrimination based on genetic status is also contained in Articles 2, 5, 7 of the document.

At the regional level, the main document containing provisions on combating genetic discrimination is the Council of Europe Convention for the Protection of Human Rights and Dignity of the Human Being with regard to the Application of Biology and Medicine: 1997 Convention on Human Rights and Biomedicine (Oviedo Convention). As mentioned above, this Convention contains a general prohibition on all forms of discrimination based on genetic heritage (Article 11) and permits predictive genetic tests to be performed only for health purposes or for scientific research (Article 12). Prior to ratification, each State party undertakes to bring its legislation into line with the Convention, and such legislation must include appropriate sanctions, as well as a requirement for compensation for persons who suffered unnecessary harm as a result of treatment or participation in a research [9].

The Oviedo Convention and the Universal Declaration on the Human Genome and Human Rights were the first legal instruments to combine international law with issues of genetic discrimination. The United Nations Economic and Social Council (ECOSOC) Resolution 2001/39 calls on states to ensure that no one is exposed to discrimination based on genetic characteristics and take measures to prevent the use of genetic information and genetic testing results that discriminate against individuals in the social, medical and labor spheres in the public or private sector. The Resolution of July 21, 2004 on similar issues contains analogous provisions [10].

In October 2003, UNESCO adopted the International Declaration on Human Genetic Data. This document establishes the legal principles governing the collection, processing, use and storage of human genetic data. Article 1 (c) of the Declaration contains an important provision. The Declaration applies to the collection, processing, use and storage of human genetic data, human proteomic data and biological samples, except in the investigation, detection and prosecution of criminal offences and in parentage testing that are subject to domestic law that is consistent with the international law of human rights. Article 3 is one of the most important in the document. It reads that each individual has a characteristic genetic make-up. However, human identity should not be limited to genetic characteristics, since it is formed under the influence of a complex of educational, environmental and personal factors, as well as emotional, social, spiritual and cultural ties with other people and presupposes an element of freedom [11].

In addition, it is worth mentioning article 7 of the Declaration. Its provisions address issues of nondiscrimination and countering stigmatization of certain groups. At the same time, it is noted that it is necessary to pay due attention to the results of population-based genetic studies and behavioral genetic studies and their interpretation [12].

The prohibition of discrimination and stigmatization is also contained in article 11 of the UNESCO Universal Declaration on Bioethics and Human Rights, adopted in 2005. The purpose of adopting anti-discrimination provisions is to introduce the prohibition of discrimination that affects human rights, fundamental freedoms and human dignity. At the same time, genetic discrimination is often distinguished from discrimination based on health status, which has been repeatedly emphasized in the academic literature. Genetic discrimination is associated with a negative attitude towards a person or a group of persons on the basis of their probable predisposition to a certain disease. Discrimination based on health status implies unfair treatment due to the presence of a disease in a person or group of people.

This approach seems to be fair in the context of the need to ensure effective protection of human rights, taking into account the specificity of genetic information. In addition, identifying discrimination based on genetic status as a special kind of discriminatory practices will contribute to the development of scientific research, taking into account ethical and legal standards adopted at the international level. Also, attention is drawn to the vagueness of the concept of genetic discrimination in the sources of international law or the complete absence of such, which, on the one hand, "unties the hands" of the national legislator, and on the other hand, deprives him of the reference point in the development of appropriate domestic regulation [13].

\section{Genetic Discrimination Issues in Foreign Legislation}

It happens that genetic discrimination affects three main areas: employment, insurance, services. The issues of discrimination based on the genetic status of the most vulnerable groups of the population, which include, among other things, ethnic communities and indigenous peoples, are considered separately. At the national level, a number of states have adopted legal acts aimed at combating discrimination based on genetic status. At the same time, two main approaches are applied to the legal regulation of this issue.

The first approach is the introduction of restrictions on freedom of contract in the field of employment and 
insurance, which theoretically can contribute to the emergence of general prohibitions of discrimination on the basis of genetic status or sectoral legal regulation in this part for insurance companies and employers. Thus, insurers and employers may be prohibited from requiring an applicant to undergo genetic testing or provide previous test results. Within the framework of the first approach, we can also talk about the ban on the use of test results when making certain decisions that may negatively affect the applicant (when calculating payments to the insured person or when assigning certain tasks to an employee or applicant). The second approach is characterized by the adoption of comprehensive legislation to protect genetic data from unauthorized collection, use and disclosure without the consent of the parties concerned, with a few exceptions. Certain jurisdictions have laws that protect patients' rights and give them greater authority to determine and decide how genetic information may be used and when. Let us consider the experience of leading jurisdictions in combating discrimination based on genetic status.

\section{United States of America}

In 2008, the USA passed the Genetic Information Nondisclosure Act (short name - GINA), which is limited to considering genetic testing in the context of health insurance and employment. At the same time, the provisions of the Act do not apply to life, disability and long-term care insurance [7]. This document is primarily aimed at determining in which cases genetic testing can be performed for research purposes. In addition, it is stated that for regulatory purposes, the reference to "genetic information of an individual" also includes a fetus or embryo. The Act prohibits the adjustment of insurance premiums in connection with certain genetic information as part of a collective insurance agreement. The document provides an opportunity for workers to file complaints against their employers in the event that there was discriminatory treatment based on genetic status. At the same time, the document discloses cases and conditions when mandatory genetic testing may be required. In particular, it may be necessary for "genetic monitoring of the biological effects of toxic substances in the workplace", subject to the requirement to ensure confidentiality [14].

\section{Australia}

Australian law explicitly prohibits discrimination based on genetic status. In 1992, the Commonwealth of Australia passed the Disability Discrimination Act 1992 containing a similar provision. At the same time, the regulations allow discrimination in relation to the insurance sector where there are sufficient grounds. Insurers have the right to use information on the results of genetic testing, even in the absence of obvious signs of the disease, in order to refuse insurance payments or increase insurance premiums in the case of life, income, travel insurance. However, the legislator emphasizes that the discriminatory attitude must be reasonably justified [15].

If we consider the legal framework for regulating non-discrimination in the field of insurance in a comprehensive manner, it should be noted that regulation is formed at three levels: federal, state and individual territories. At the federal level, there are the following main acts affecting aspects of discrimination in insurance: the Sex Discrimination Act 1984, the Racial Discrimination Act 1975 and the 1992 Disability Discrimination Act. Moreover, the 1984 and 1992 Acts contain special provisions on the admissibility of discrimination in the field of insurance in the presence of certain circumstances. The 1975 Act does not contain such a provision. At the same time, it limits the information that insurers are allowed to use in underwriting applications, to guarantee the receipt of payments in the event of an insured event. Thus, insurers cannot differentiate between applicants on the basis of race, although life expectancy for Indigenous Australians is known to be markedly lower than that of the Caucasian population as a whole. As for the legislation at the state and individual territories level, in each specific case, it represents an independent regulation in the field of insurance and non-discrimination [17, 4].

\section{Canada}

Until 2017, there was no comprehensive regulation on genetic discrimination in Canada. It was in 2017 that the Genetic Discrimination Act was passed by the Parliament of Canada. This document, along with amendments to the Labor Code of Canada and the Canadian Human Rights Act, prohibits companies and employers from demanding the results of genetic tests or participation in genetic testing from employees and applicants [16].

The Act introduces a ban for individuals and legal entities to require the results of genetic tests when providing services or selling goods, entering into a contractual relationship. In addition, the document prohibits the refusal of services when a person gives up undergoing genetic tests. The collection, use and disclosure of the results of human genetic tests without written consent are "outlawed" [17].

This Act applies to the field of employment and insurance. Insurance companies, along with organizations - employers, also cannot demand the results of genetic tests. The Canadian Life and Health Insurance Association currently has a voluntary code that insurers will not require genetic tests, but the results of previous tests must be disclosed if the insurance policy is over $\$ 250,000$. It should be noted that about $15 \%$ of Canadians have insurance policies that exceed this amount [18].

In 2019, in one of the Canadian courts, the question arose about the unconstitutionality of the document in question. It is worth mentioning the case of the Canadian Coalition for Genetic Fairness v. Attorney General of Quebec, et al., in which the Provincial Government of Quebec made a prejudicial request to the 
Quebec Court of Appeal. The competence to adopt acts in this area at the federal level, and not at the provincial level, was questioned. In July 2020, the Supreme Court of Canada ruled that the Act did indeed come under federal jurisdiction. As a result, it was found that the document is valid and must be followed by all throughout Canada. The decision of the court demonstrated that the Act takes precedence over provincial laws in respect of any dispute in the designated area. Thus, as detailed in the decision, provincial legislation requiring individuals applying for health or life insurance to disclose all material health information will not have the effect of seeking genetic test results from individuals.

\section{Judicial Practice in the Field of Combating Genetic Discrimination}

In the field of combating discrimination based on genetic status, a number of states have developed judicial practice. The experience of the United States is remarkable in this context. Thus, the Commission for Equal Employment Opportunities was involved in resolving a dispute related to filing a claim against an employer who violated the 2008 GINA. The essence of the violation was that the employer requested a family medical history from its employees and applicants in violation of the provisions of this Act (EEOC $v$. BNV Home Care Agency, Inc.).

It should be noted that the Commission filed a lawsuit on its own behalf and an undefined group of persons, since the activities of the defendant company grossly violated the requirements of the Genetic Information Nondisclosure Act. The parties managed to resolve the dispute in October 2016. The defendant agreed to the imposition of an injunction against continuing violations of the provisions of the Act. The company went through to destroy all questionnaires containing confidential information about the diseases of employees and applicants since 2014, and transform the content of the questionnaire in order to bring it in line with the requirements of American law. The defendant also paid USD 125,000 in damages (this amount was divided equally among the employees).

A high-profile case involving the issue of countering discriminatory practices related to the conduct of genetic research (expertise) was the case of Lowe v. Atlas Logistics Group, which confirmed that the Genetic Information Nondisclosure Act is characterized by its breadth of application.

What were the circumstances of the case? The respondent company Atlas Logistics specialized in providing services for the delivery and storage of products. In 2012, one of the company's employees began to defecate in one of the warehouses, thereby harming both the products in the warehouse and the health of people who could be potential buyers of such products. To identify the employee, the company seized genetic samples from two warehouse workers who were suspected of being involved in the "joke".
Two employees agreed to provide their genetic information, and the defendant company hired a forensic laboratory to check if the DNA samples matched the excrement found in the warehouse. The results of laboratory tests did not confirm the participation of these employees in the "drawing"; nevertheless, information about such testing was disseminated among other employees of the company.

As a result, employees filed a lawsuit in the federal district court of Georgia, claiming that DNA testing initiated by Atlas violated the Genetic Information Nondisclosure Act 2008, which prohibits employers from requesting the so-called "genetic information" from their employees. As a result, Judge Amy Totenberg ruled in favor of the warehouse workers, while the issue of damages was decided by a jury trial. The judge dismissed the defendant's argument that the Act contained a prohibition on requesting information solely about a person's propensity to get sick, noting that the Act covered a wider range of testing. It is noteworthy that the jury's verdict in this case was positive for the staff, in particular, the jury awarded two officers an impressive amount of compensation in the amount of $\$$ 2.2 million ( $\$ 475,000$ in damages and $\$ 1.75$ million in penalties).

This case was a confirmation of the inadmissibility of violating the provisions of the GINA, since the consequences of employers' unwillingness to act in accordance with its instructions are quite severe. A request for genetic information and a requirement to undergo genetic testing conflicts with US antidiscrimination laws on the basis of genetic status, regardless of motive. For example, to identify worker misconduct in the interests of health and safety and employer's desire to reference and use genetic information for the purpose of employment and assessment of the possibility of continuing labor relations.

Discriminatory practices often manifest themselves in relation to the use of "incomplete" informed consent for biomaterials from representatives of ethnic communities. Noteworthy in this context is the American case Havasupai Tribe v. Arizona Board of Regents, which addressed the use of tribal DNA samples for purposes other than the original collection of genetic data. The case was resolved in favor of the tribe: tribal members received $\$ 700,000$ in direct compensation, funds for the tribal clinic and school, and, most importantly, from the point of view of individual tribesmen, the return of DNA samples. The genetic material was to be disposed of in a specialized ceremony [19].

The Havasupai case challenged the concept of informed consent, especially for vulnerable populations, pointing out that extended consent forms and incomplete disclosures did not lead to a full understanding of the research needed to make a truly informed decision to participate in health projects. It also raised the issue of the need to conduct research with the participation of indigenous peoples in a fair, non-discriminatory manner, including addressing the issue of how to deal with "old" DNA samples and "old" informed consent when 
working with the participants in genetic research. DNA samples have unquestionable value, but as they «mature», they become less usable, and long-time informed consent prevents the use of samples today. The Havasupai case also raises the question of how we should use the original, "old" but valuable DNA samples before the legal community [20, 21].

Legal regulation of the use of genetic information of the most vulnerable groups of the population in scientific research requires a special approach from the point of view of ensuring a balance of legal regulation and traditions, ethics and law. The law enforcement practice of the United States in this matter clearly demonstrates the emerging tendency to take into account human rights (the rights of indigenous peoples) when deciding on the transfer of biomaterials and their secondary use in scientific research.

\section{Conclusions. Problems of the Implementation of Foreign Experience in the Field of Combating Genetic Discrimination into Russian Legislation}

The proliferation of genetic testing makes it necessary to develop appropriate legal regulation of relations arising from countering discriminatory practices that may arise in connection with the use of this information in the field of employment, insurance and other areas of public life. In this context, the experience of the states considered in the article can be useful to the Russian legislator in order to develop a comprehensive legal regulation of the use of genetic information, including in the aspect of preventing discrimination based on genetic status. It is noteworthy that the provisions of the US GINA 2008 and the Canada Genetic Discrimination Act 2017 contain a significant ethical component, which is specified by law enforcement practice. The unconditional protection of the confidentiality of identifiable genetic information proclaimed by these acts and the general prohibition of genetic discrimination in hiring and concluding health insurance contracts is supplemented by a number of exceptions. For example, the prohibition of discrimination does not affect life insurance, which is a means of ensuring a balance of interests of participants in legal relations in the field of insurance and employment. At the same time, law enforcement practice demonstrates the priority of protecting the interests of persons whose genetic information is claimed by employers and insurance organizations.

At the same time, it should be noted that the legislative means of protection against discrimination in force in the reviewed states are not always effective, because the law extends its effect to a limited number of spheres of life and leaves loopholes for the use of discriminatory practices in order to reduce health care costs. Taking into account the upward trend in health care costs, the prohibition of discrimination based on genetic status needs substantive clarification.

Nevertheless, some of the approaches and principles developed in the law of states considered in this article, as well as in judicial practice, can also be used to form an effective mechanism to ensure a balance of private, group and public interests in the field of legal regulation of genomic research. When drafting the Russian legal regulation in the field of combating discrimination based on genetic status, it is necessary to take into account the indicated problems.

This article is based on the results obtained within the framework of the state assignment of the Ministry of Education and Science of Russia 730000Ф.99.1.БB16AA02001 ('Scientific and methodological support', Kutafin Moscow State Law University), the Russian Foundation for Basic Research grants 18-29-14078 MK and 18-29-14054 MK.

\section{References}

1. J. Gerards, A.W. Herringa, H.L. Janssen, Genetic discrimination and genetic privacy in a comparative perspective (Insertia, 2005)

2. I.A. Motoc, International law of genetic discrimination (New Technologies and Human Rights, Oxford University Press, 2009)

3. A. Gammon, D.W. Neklason, Surg. Oncol. Clin. N. Am., 24, 4 (2015)

4. T. Lemke, Genomics, Society and Policy, 1, 3 (2005)

5. K.S. Gadzhiev, K.N. Gusov, Discrimination (Big Russian Encyclopedia. Electronic version, 2017)

6. C.R. Chapman, K.S. Mehta, B. Parent, A.L. Caplan, Journal of Law and the Biosciences, 7, 1 (2020)

7. C. Dupras, L. Song, K.M. Saulnier, Y. Joly, Front. Genet., 9 (2018)

8. M. Hao, A.S. Macdonald, P. Tapadar, ASTIN Bull. J. IAA, 46, 2 (2016)

9. M.B. Steck, E. Hassen, Semin. Oncol. Nurs., 35, 1 (2019)

10. J. Tiller, M. Otlowski, P. Lacaze, Front. Public Health, 5 (2013)

11. M. Underhill-Blazey, M.R. Klehm, Clin. J. Oncol. Nurs., 24, 2 (2020)

12. S. Taylor, S. Treloar, K. Barlow-Stewart, M. Stranger, M. Otlowski, Clin. Genet., 74, 1 (2008)

13. E.A. Feldman, J. Gen. Intern. Med., 27, 6 (2012)

14. A.K. Smit, D. Espinoza, A.J. Newson, R.L. Morton, G. Fenton, L. Freeman, Cancer Epidemiol. Biomarkers Prev., 26, 2 (2017)

15. M. Otlowski, S. Taylor, Y. Bombard, Annu. Rev. Genomics Hum. Genet., 13 (2012)

16. C.J. Adams, C.A. Donnelly, A.S. Macdonald, Br. Actuar. J., 20 (2015)

17. E.M. Sorokina, D.V. Ponomareva, Indigenous Peoples' Rights and Genomic Research in the United States: The Havasupai Case (International Legal Courier, 2020)

18. S. Flynn, Semin. Oncol. Nurs., 35, 1 (2019)

19. L.A. Keogh, M.F. Otlowski, Med. J. Aust., 199, 5 (2013) 
20. M. A. Rothstein, Hastings Center Report, 48, 3 (2018)
21. L.M. Slaughter, Surg. Clin. North Am., 88, 4 (2008) 